\title{
Delineation of PCB uptake pathways in a benthic sea star using a radiolabelled congener
}

\author{
B. Danis ${ }^{1, *}$, O. Cotret $^{2}$, J. L. Teyssié ${ }^{2}$, S. W. Fowler ${ }^{2}$, P. Bustamante ${ }^{3}$, M. Warnau ${ }^{2}$ \\ ${ }^{1}$ Laboratoire de Biologie Marine (CP 160/15), Université Libre de Bruxelles, Avenue F. D. Roosevelt 50, \\ 1050 Brussels, Belgium \\ ${ }^{2}$ International Atomic Energy Agency, Marine Environment Laboratory, 4 Quai Antoine Ier, BP 800, 98012 Monaco \\ ${ }^{3}$ Laboratoire de Biologie et d'Environnement Marins, UPRES-EA 3168, Université de La Rochelle, 22 Avenue Michel Crépeau, \\ 17042 La Rochelle, France
}

\begin{abstract}
Asterias rubens (Linnaeus, 1758), a common sea star in North Sea waters, was selected to study the bioaccumulation of an important polychlorinated biphenyl congener, ${ }^{14} \mathrm{C}$-labelled PCB\#153, from 2 contrasting sources: seawater and sediments. After 4 wk acclimation to laboratory conditions, sea stars were exposed for $34 \mathrm{~d}$ to realistic concentrations $\left(30 \mathrm{ng} \mathrm{l}^{-1}\right.$ in seawater and $9.5 \mathrm{ng}$ $\mathrm{g}^{-1}$ dry wt in sediments) of the contaminant during which time bioaccumulation of PCB\#153 was followed in 6 body compartments. The results showed that (1) for each body compartment, PCB uptake kinetics were generally asymptotic and bioaccumulation was far greater when A. rubens was exposed via seawater than via sediments; (2) body wall and podia were the body compartments showing the greatest affinity for the PCB congener, making them ideal tissues for biomonitoring purposes; (3) the concentrations reached in body compartments were within the range of values reported in several field studies. Because radioisotopic techniques are extremely sensitive, they allow key organs that are sometimes too small for standard analysis of PCBs to be taken into account.
\end{abstract}

KEY WORDS: Polychlorinated biphenyls · PCB\#153 - Bioaccumulation · Kinetics · Asterias rubens · Echinoderm Resale or republication not permitted without written consent of the publisher

\section{INTRODUCTION}

Polychlorinated biphenyls (PCBs) are strictly anthropogenic chemicals that constitute one of the most problematic and widespread group of contaminants. These xenobiotics, represented by 209 congeners, are extremely resistant to degradation (physico-chemical or biological), are bioconcentrated by living organisms, and can cause various adverse effects depending on their pattern and degree of chlorine substitution (Metcalfe 1994). For PCBs entering the marine environment, bottom sediments are the ultimate repository where they may become a source for uptake by marine organisms through direct or indirect contact or, for filter-feeders, by ingestion; however, information about their impact on benthic species is relatively scarce (Chapman 1995, Carr et al. 1996, Wood et al. 1997).
According to various authors, the asteroid Asterias rubens qualifies as an excellent bioindicator organism for monitoring heavy metal contamination in the North Sea and NE Atlantic benthic ecosystems (Knickmeyer et al. 1992, den Besten et al. 1993, Everaarts et al. 1998, Temara et al. 1998, Warnau et al. 1999). It is indeed a widely distributed and abundant key species (sensu Lewis 1978) that is easy to collect, identify and maintain in the laboratory. In addition, A. rubens is a top predator, feeding mainly on mussels, and lives on or in proximity to bottom sediments, which are the main reservoir of many contaminants, including PCBs. The biological and ecological characteristics of A. rubens as well as its potential economic impact (as a predator of commercially important mussels) have led some authors to use this species as a tool to assess the degree of PCB contamination in the North Sea (den Besten et 
al. 1989, 1993, Everaarts et al. 1998). However, to the best of our knowledge, no study has investigated PCB bioaccumulation processes in A. rubens. The only 2 experimental studies investigating PCB bioaccumulation in echinoderms concern sea urchins exposed to contaminated sediments (Weisberg et al. 1996, Schweitzer et al. 2000), and only Weisberg et al. (1996) examined the kinetic aspects of PCB uptake.

Such data are however needed to further assess the value of Asterias rubens as a bioindicator of PCB contamination. Therefore, in the present study, we have investigated the kinetics of PCB uptake in A. rubens exposed either to the contaminant in seawater or associated with sediments, i.e. the 2 extreme pathways of contamination from the viewpoint of absolute PCB concentrations. Indeed, the high hydrophobicity of PCBs result in a characteristic partitioning, with concentrations in natural seawater typically in the range of pg to $\mathrm{n} \mathrm{l}^{-1}$ while sediment concentrations are in the range of $\mu \mathrm{g}$ to $\mathrm{mg} \mathrm{kg}^{-1}$ (see Table 1). The PCB congener IUPAC \#153 $\left(2,2^{\prime}, 4,4^{\prime}, 5,5^{\prime}\right.$ hexachlorobiphenyl) was selected because it is the most abundant in marine biota (Stebbing et al. 1992) and has been shown to be an excellent indicator of total PCB contamination (Atuma et al. 1996).

\section{MATERIALS AND METHODS}

Sampling. Sea stars Asterias rubens (Linnaeus, 1758) were collected in April 1999 from the intertidal zone at Audresselles (Pas-de-Calais, France). Prior to experimentation, specimens were acclimated to laboratory conditions for 1 mo in constantly aerated closed-circuit aquaria (salinity $36 \%, T 16 \pm 0.5{ }^{\circ} \mathrm{C}, 12 / 12 \mathrm{~h}$ dark/light cycle).

In order to follow PCB\#153 bioaccumulation under realistically simulated conditions, a ${ }^{14} \mathrm{C}$-labelled congener was used and measured using highly sensitive $\beta$-spectrometry.

Radiotracer. The ${ }^{14} \mathrm{C}$-labelled $2,2^{\prime}, 4,4^{\prime}, 5,5^{\prime}$ hexachlorobiphenyl (purity $\geq 95 \%$ ) was purchased from Sigma Chemicals, USA. Specific activity was $925 \mathrm{MBq}$ $\mathrm{mmol}^{-1}$. Stock solutions were prepared in acetone at a concentration of $1 \mathrm{\mu g} \mathrm{ml}^{-1}$.

Sample treatment and liquid scintillation counting. Water samples $(2 \mathrm{ml})$ were directly transfered to $20 \mathrm{ml}$ glass scintillation vials (Packard) and $10 \mathrm{ml}$ of Ultima Gold $\mathrm{XR}^{\circledast}$ (Packard Instruments) scintillation liquid were added. Samples of sediment and sea star tissue (previously crushed) were placed in a vial containing $2 \mathrm{ml}$ of Acetonitrile ${ }^{\circledR}$ in an ultrasonic bath for $10 \mathrm{~min}$. Acetonitrile ${ }^{\circledR}$ was then collected and replaced by another $2 \mathrm{ml}$ of Acetonitrile ${ }^{\circledR}$ and the ultrasonic operation was repeated a second time. This treatment gave $4 \mathrm{ml}$ of liquid phase (viz. the extraction) and a residue. The residue was digested overnight at $70^{\circ} \mathrm{C}$ with $2 \mathrm{ml}$ of Soluene ${ }^{\circledR}$, and $10 \mathrm{ml}$ of Hionic Fluor ${ }^{\circledR}$ scintillation liquid were then added. The liquid phase $(4 \mathrm{ml})$ was added to $16 \mathrm{ml}$ of filtered seawater and extracted twice using $2 \mathrm{ml}$ of n-Hexane (Sigma) under constant agitation. The organic phase $(4 \mathrm{ml})$ and the aqueous phase $(20 \mathrm{ml})$ were treated separately. The entire organic phase and $2 \mathrm{ml}$ of the aqueous phase were each added separately to $10 \mathrm{ml}$ of Ultima Gold $\mathrm{XR}^{\circledR}$ scintillation liquid.

${ }^{14} \mathrm{C}$-radioactivity was then measured using a $1600 \mathrm{TR}$ Liquid Scintillation Analyzer (Packard), compared to standards of known activities, and corrected for quenching, background and physical decay of the radiotracer. Counting times were adjusted to obtain counting rates with relative propagated errors less than $5 \%$. PCB concentrations were expressed on a total lipid content basis, whereby lipids were determined according to the method of Barnes \& Blackstock (1973). A schematic diagram of the sample treatment is shown in Fig. 1.

Experimental procedures. Uptake from seawater and sediments was measured as follows.

Uptake from seawater: Asteroids $(\mathrm{n}=24)$ were placed for $34 \mathrm{~d}$ in a $70 \mathrm{l}$ glass aquarium (constantly aerated closed-circuit aquaria; salinity $36 \%$, T $16 \pm 0.5^{\circ} \mathrm{C}$, $12 / 12 \mathrm{~h}$ dark/light cycle) containing natural seawater spiked with ${ }^{14} \mathrm{C}$-labelled PCB\#153; $1 \mathrm{~d}$ prior to the experiments, four $5 \mathrm{l}$ glass beakers were filled with filtered seawater $\left(36 \%, 16 \pm 0.5^{\circ} \mathrm{C}\right)$, spiked with the radiolabelled $\mathrm{PCB}$ stock solution, and constantly stirred using an orbital agitation plate. Contaminated water was then poured into the glass aquaria, and uncontaminated seawater was added to obtain a final volume of $70 \mathrm{l}$. Sea water and radiotracer were renewed every second day during the entire experiment. Activity was checked before and after each renewal to assess the stability of the labelled PCB concentration in the seawater (Table 1). The sea stars were fed unlabelled mussels Mytilus edulis every second day just before seawater renewal. After $2 \mathrm{~h}$, uningested mussels were removed to limit PCB incorporation via the food as much as possible. Periodically (after 2, 4, 7, 11, 14, 21 and $34 \mathrm{~d}$ ), sea stars $(\mathrm{n}=3$ ) were removed, dissected into 7 body compartments (oral and aboral body walls, central digestive system, gonads, rectal caeca, pyloric caeca, and podia), and radioanalyzed to determine uptake kinetics and body distribution of the incorporated PCB.

Uptake from sediments: Sediments (2.5 kg dry wt) from the North Sea (Audresselles, Pas-de-Calais, France) were contaminated for $4 \mathrm{~d}$ with the ${ }^{14} \mathrm{C}$ labelled PCB using the rolling-jar method (jars constanty stirred on an orbital agitation plate) (Murdoch et al. 1997). Sea stars $(n=24)$ were placed in a 701 glass aquarium (constantly aerated open circuit aquarium; 


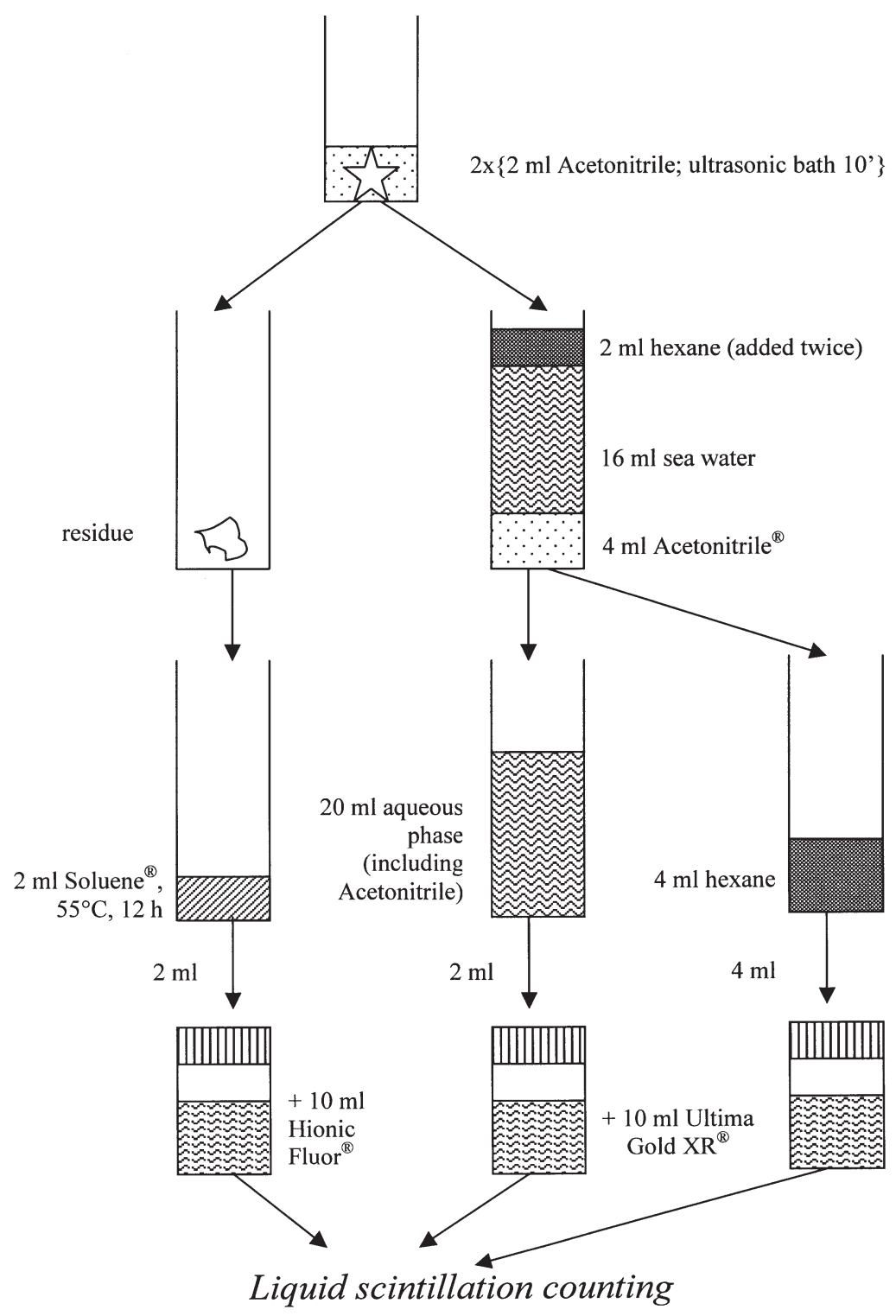

Fig. 1. Schematic representation of sample processing before $\beta$-spectrometry analysis

salinity $36 \%, \mathrm{~T} 16 \pm 0.5^{\circ} \mathrm{C}, 12 / 12 \mathrm{~h}$ dark/light cycle) containing a $10 \mathrm{~cm}$ layer of seawater running over a $2 \mathrm{~cm}$ layer of spiked sediments. A separate group of 5 sea stars was placed in the same aquaria, but in another compartment (not in contact with the sediments), to serve as a control for possible cross-contamination through seawater. The sea stars were fed every second day with mussels Mytilus edulis. Uningested food was removed after $2 \mathrm{~h}$. The radioactivity of the labelled PCB was measured weekly in the sediments to check for possible leaching (Table 1). Periodically (after 2, 4, $7,11,14,21$, and $34 \mathrm{~d}), 3$ individuals were removed, dissected as described above, and their tissues counted for radioactivity.
Data analyses. Uptake of the PCB congener from seawater and sediments was expressed as change in PCB concentration (ng $\mathrm{g}^{-1}$ total lipids) over time. Uptake kinetics were described either by using a saturation exponential model (Eq. 1), a single-component exponential model (Eq. 2), or a combined model (logistic and single-component exponential) (Eq. 3):

$$
\begin{aligned}
& C(t)=C S S\left(1-\mathrm{e}^{-\mathrm{k} t}\right) \\
& C(t)=C(0) \mathrm{e}^{\mathrm{k} t} \\
& C(t)=C S S\left(1-\mathrm{e}^{-\mathrm{k} t}\right) / 1+\mathrm{e}^{-\mathrm{k}(t-I)}
\end{aligned}
$$

where $C(t), C(0)$, and Css are the PCB concentrations (ng $\mathrm{g}^{-1}$ total lipids) at Time $t(\mathrm{~d})$, at Time 0 and at steady state, respectively, $\mathrm{k}$ is the rate constant $\left(\mathrm{d}^{-1}\right)$, and $I$ is the time (d) at the inflexion point. The model showing the best fitting accuracy (based on the calculation of the determination coefficient, $\mathrm{R}^{2}$, and examination of the residuals) was used.

Constants of the different models and their statistics were estimated by iterative adjustment of the models and Hessian matrix computation, respectively, using the nonlinear curve-fitting routines in the Systat $^{\circledR}$ 5.2.1 software (Wilkinson 1988). Differences between PCB concentrations in the different sea star body compartments were tested by 1-way ANOVA and the multiple comparison test of Tukey (Zar 1996). Changes in PCB body distribution were tested for significance using the $G$ test (adapted from the log-likelihood ratio test) for $2 \times \mathrm{k}$ contingency tables (Zar 1996). Prior to the latter test, data were arcsine-transformed using the correction of Freeman-Tukey (1950; described by Zar 1996). The level of significance for statistical tests was always set at $\alpha=0.05$.

\section{RESULTS}

The uptake of PCB\#153 by Asterias rubens was investigated through separate exposures to contaminated seawater or sediments. As differences between accumulation kinetics in aboral and oral body walls were never found in any experiment ( $p$ always $>0.1$ ), these 2 compartments were pooled and are presented as a single compartment (body wall) throughout the text. The uptake kinetics of PCB congener \#153 in 6 different body compartments (body wall, central digestive system, gonads, rectal caeca, pyloric caeca, podia) 
Table 1. Characteristics of background and added concentrations of PCB\#153. Background concentrations were measured in seawater, sediments and sea stars (body wall and pyloric caeca) the day before starting the experiment; added concentrations were measured in subsamples of seawater and sediments regularly collected during laboratory microcosm throughout the experiment. Ranges of values of PCB\#153 (unless specified otherwise) reported for seawater and sediments in the field are given for comparison. sum $_{7}$ : sum of concentrations of the 7 PCB congeners typically recommended by international organisations such as NSTF and EU, sum hexa: sum of hexachlorinated congeners

\begin{tabular}{|c|c|c|c|}
\hline Compartment & PCB conc. & Location & Source \\
\hline \multicolumn{4}{|l|}{ Background } \\
\hline Seawater $\left(\mathrm{ng} \mathrm{l}^{-1}\right)$ & $0.026(\mathrm{n}=6)$ & & \\
\hline Sediments (ng g ${ }^{-1}$ dry wt) & $0.017(\mathrm{n}=6)$ & & \\
\hline Body wall (ng g ${ }^{-1}$ lipids) & $559 \pm 17(\mathrm{n}=6)$ & & \\
\hline Pyloric caeca (ng g ${ }^{-1}$ lipids) & $522 \pm 167(\mathrm{n}=6)$ & Southern North Sea & Present study \\
\hline \multicolumn{4}{|l|}{ Added } \\
\hline \multicolumn{4}{|l|}{ Seawater } \\
\hline Sediments (ng g ${ }^{-1}$ dry wt) & $9.49 \pm 1.14(\mathrm{n}=12)$ & & \\
\hline \multicolumn{4}{|l|}{ Field values } \\
\hline \multicolumn{4}{|l|}{ Seawater } \\
\hline dissolved $\left(\mathrm{pg} \mathrm{l}^{-1}\right)$ & $0.1-67.2$ & Baltic Sea & Shultz-Bull et al. (1995) \\
\hline \multirow{4}{*}{ dissolved + particulate $\left(\mathrm{ng} \mathrm{l}^{-1}\right)$} & 0.8-8.7 (Aroclor 1260) & Atlantic Ocean & Harvey \& Steinhauer (1976) \\
\hline & 1.5-38.0 (Phenoclor DP-5) & Mediterranean French coasts & Elder (1976) \\
\hline & $\begin{array}{l}0.2-370 \text { (Phenoclor } \\
\text { DP-5/DP-6) }\end{array}$ & $\begin{array}{l}\text { Mediterranean and Atlantic } \\
\text { French coasts }\end{array}$ & Marchand et al. (1990) \\
\hline & $0.34-4.93$ (sum hexa-CB) & Marmara Sea & Telli-Karakoç et al. (2002) \\
\hline \multicolumn{4}{|l|}{ extreme hot spot $\left(\mu g \mathrm{l}^{-1)}\right.$} \\
\hline dissolved: & $1.8 \pm 0.3$ & New Bedford Harbor, USA & Bergen et al. 1996 \\
\hline particulate: & $14 \pm 3.9 \mu \mathrm{g} \mathrm{l} \mathrm{l}^{-1}$ & & \\
\hline \multirow[t]{3}{*}{ Sediments (ng g ${ }^{-1}$ dry wt) } & $22-4060$ & North Sea, German Bight & Stebbing et al. (1992) \\
\hline & $0.27-47\left(\mathrm{sum}_{7} \mathrm{PCB}\right)$ & North Sea, Dutch coastal zone & Boon et al. (1985) \\
\hline & $2.2-32\left(\mathrm{sum}_{7} \mathrm{PCB}\right)$ & North Sea, Dutch coastal zone & Laane et al. (1999) \\
\hline
\end{tabular}

are shown in Figs. 2 \& 3 for the seawater and sediment exposures, respectively.

\section{Contamination via seawater}

Depending on the body compartment, accumulation from seawater was best described by a combined (logistic and exponential) model (viz. uptake in body wall, gonads, pyloric caeca, and podia) or a singlecomponent exponential model (viz. uptake in central digestive system and rectal caeca) (Fig. 2, Table 2).

The body wall was the compartment that concentrated ${ }^{14} \mathrm{C}$-PCB\#153 to the greatest degree, up to 2 orders of magnitude higher than the rectal caeca $\left(\mathrm{p}_{\text {Tukey test }} \leq 0.0001 ;\right.$ Table 3$)$.

Body distribution of incorporated ${ }^{14} \mathrm{C}$-PCB\#153 varied significantly along the timecourse of the experiment $\left(\mathrm{p}_{\mathrm{G}-\mathrm{test}}<0.05\right)$. Initially, the contaminant was mostly present in the podia ( $74 \pm 5 \%$ of total body load after $2 \mathrm{~d}$ exposure) and secondarily in the body wall $(26 \pm 5 \%)$. Progressively, the proportion of the PCB associated with the body wall increased, reaching $69 \pm 5 \%$ of the total body burden after $34 \mathrm{~d}$ of exposure, while during the same time the podia proportion decreased to $7 \pm 2 \%$ (Table 4 ).

\section{Contamination via sediments}

Frequent radioanalysis of the contaminated sediments indicated that the maximum difference between measured ${ }^{14} \mathrm{C}$-PCB\#153 activities was $13.1 \%$ and that no significant decreasing trends occurred; therefore, concentrations in labelled PCB remained relatively stable throughout the $34 \mathrm{~d}$ long experiment (9.5 \pm $1.1 \mathrm{ng} \mathrm{g}^{-1}$ dry wt; see Table 1 ). Similarly, radioactivity in the seawater and in control sea stars remained below the detection limit, indicating that no significant ${ }^{14} \mathrm{C}$-PCB was incorporated from suspended sediments possibly ingested by the mussels on which they fed nor from seawater due to cross-contamination.

Accumulation from contaminated sediments was best described either by a single-component exponential model (gonads), a saturation exponential model (podia), or a combined model (body wall, central digestive system, rectal caeca and pyloric caeca) (Fig. 3, Table 2). As noted during the seawater exposure, body wall and podia were the body compartments that accumulated ${ }^{14} \mathrm{C}$-PCB\#153 to the highest levels when exposed to labelled sediments (Table 5).

The distribution of ${ }^{14} \mathrm{C}-\mathrm{PCB}$ in sea star tissues was determined at different times during the timecourse of the experiment. Relative transfers among body com- 

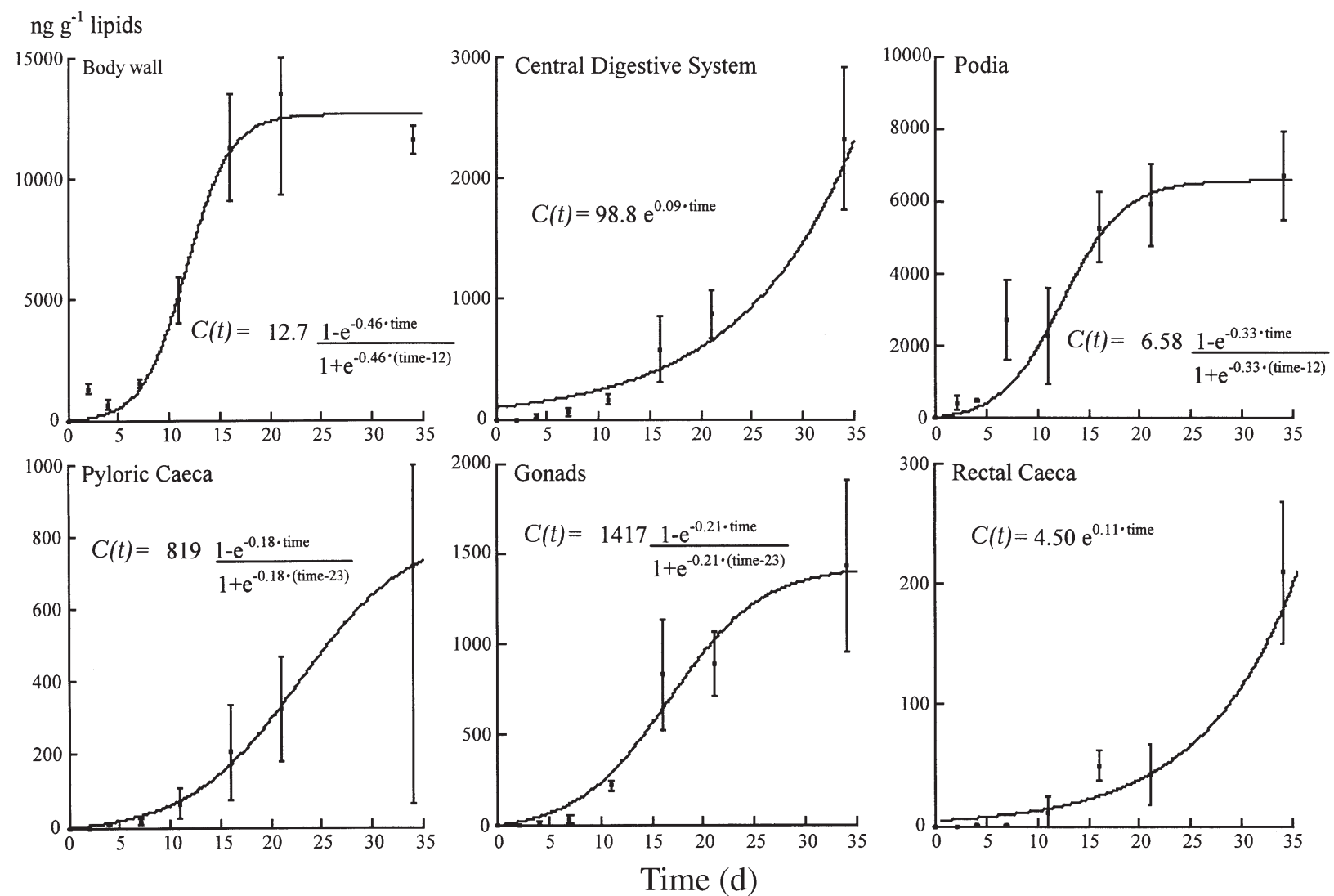

Fig. 2. Asterias rubens. Seawater experiment. Uptake of ${ }^{14} \mathrm{C}-\mathrm{PCB} \# 153$ from seawater by different body compartments (mean concentration in $\mathrm{ng} \mathrm{g}^{-1}$ total lipids $\left.\pm \mathrm{SD}, \mathrm{n}=3\right)$. $C(t)$ : concentration at Time $t$
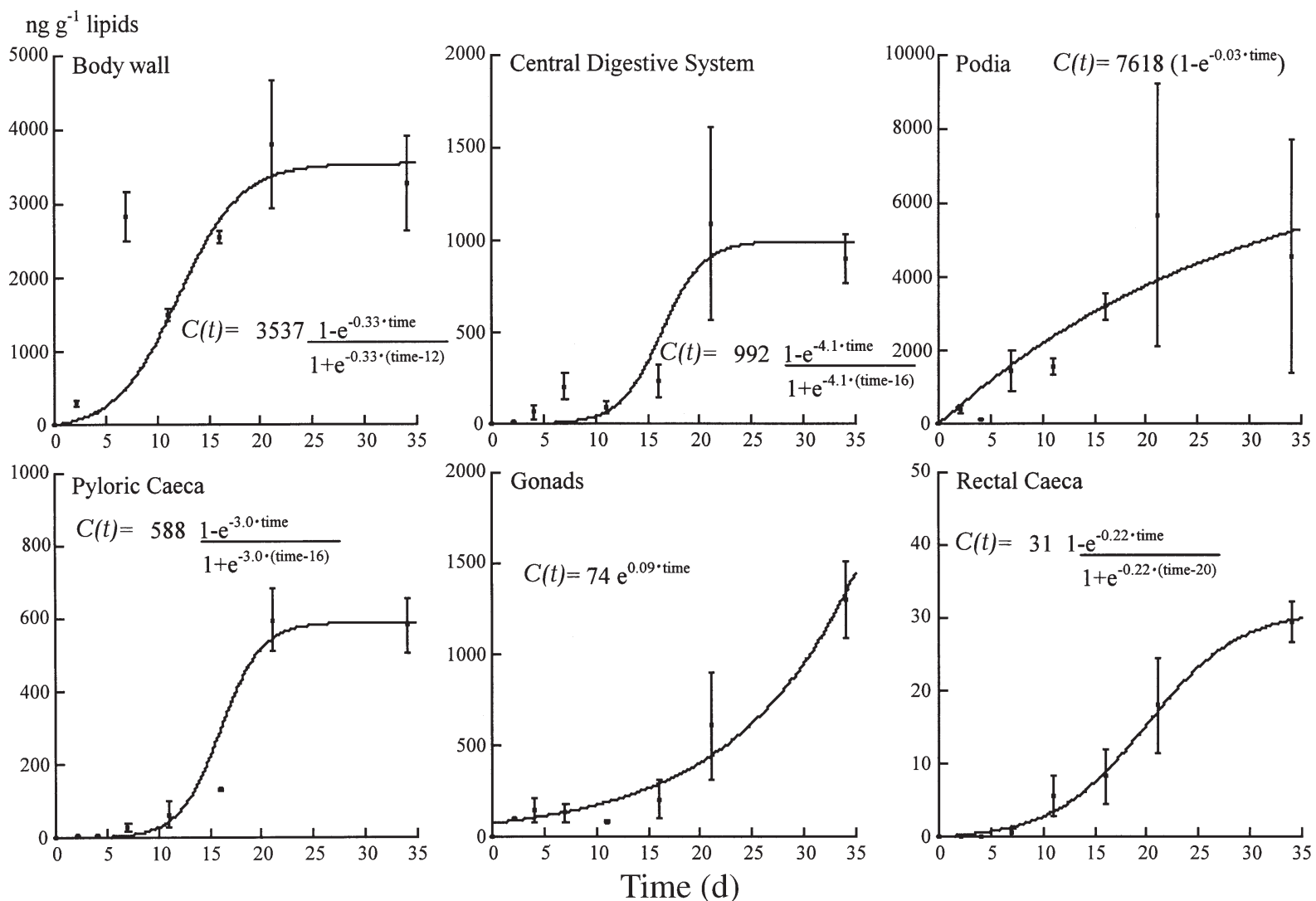

Fig. 3. Asterias rubens. Sediment experiment. Uptake of ${ }^{14} \mathrm{C}-\mathrm{PCB} \# 153$ from sediments by different body compartments of the sea star (mean concentration in $\mathrm{ng} \mathrm{g}^{-1}$ total lipids $\pm \mathrm{SD}, \mathrm{n}=3$ ) 
Table 2. Asterias rubens. Parameters and statistics of equations describing uptake of ${ }^{14} \mathrm{C}-\mathrm{PCB} \# 153$ from seawater and sediments by in body compartments. E (exponential model): $C(t)=C_{0} \mathrm{e}^{\mathrm{k} t} ; \mathrm{S}$ (saturation model): $C(t)=C s S\left(1-\mathrm{e}^{-\mathrm{k} t}\right) ; \mathrm{C}($ combined model): $C(t)=C s S\left(1-\mathrm{e}^{-\mathrm{k} t}\right) /\left(1+\mathrm{e}^{-\mathrm{k}(t-I)}\right)$; where $C_{0}, C(t), C s S={ }^{14} \mathrm{C}-\mathrm{PCB} \# 153$ concentrations (ng g ${ }^{-1}$ lipids) at Time 0 , at Time $t(\mathrm{~d})$ and at steady-state respectively, k-rate constant $\left(\mathrm{d}^{-1}\right) ; I=$ time $(\mathrm{d})$ at inflexion point; $\mathrm{ASE}=$ asymptotic standard error; $\mathrm{R}^{2}=$ corrected determination coefficient

\begin{tabular}{|c|c|c|c|c|c|c|}
\hline Body compartment & Model & $C_{0}(\mathrm{ASE})$ & CSS (ASE) & $\mathrm{k}(\mathrm{ASE})$ & $I$ (ASE) & $\mathrm{R}^{2}$ \\
\hline \multicolumn{7}{|l|}{ Seawater } \\
\hline Body wall & $\mathrm{C}$ & \multirow{3}{*}{$98.8(27.7)$} & 12665 (691) & $0.46(0.13)$ & \multirow[t]{2}{*}{$11.7(0.67)$} & 0.92 \\
\hline Central digestive system & $\mathrm{E}$ & & & $0.093(0.009)$ & & 0.77 \\
\hline Gonads & $\mathrm{C}$ & & $1417(231)$ & $0.21(0.11)$ & $23(2.8)$ & 0.90 \\
\hline Rectal caeca & $\mathrm{E}$ & \multirow[t]{3}{*}{$4.5(2.0)$} & & $0.11(0.01)$ & & 0.91 \\
\hline Pyloric caeca & $\mathrm{C}$ & & 819 (398) & $0.18(0.17)$ & $22.9(8.2)$ & 0.80 \\
\hline Podia & $\mathrm{C}$ & & $6584(449)$ & $0.33(0.12)$ & $12.4(0.87)$ & 0.93 \\
\hline \multicolumn{7}{|l|}{ Sediments } \\
\hline Body wall & $\mathrm{C}$ & \multirow{6}{*}{74 (19) } & 3537 (206) & $0.33(0.08)$ & $12(0.92)$ & 0.93 \\
\hline Central digestive system & $\mathrm{C}$ & & $992(81)$ & $4.1(29)$ & $16(2.0)$ & 0.81 \\
\hline Gonads & $\mathrm{E}$ & & & $0.085(0.008)$ & & 0.89 \\
\hline Rectal caeca & $\mathrm{C}$ & & $31(2.3)$ & $0.22(0.05)$ & $20(1.1)$ & 0.94 \\
\hline Pyloric caeca & $\mathrm{C}$ & & $588(18)$ & $3.0(11)$ & $16(1.5)$ & 0.97 \\
\hline Podia & $\mathrm{S}$ & & $7618(4266)$ & $0.034(0.029)$ & & 0.57 \\
\hline
\end{tabular}

partments appeared to be quite different from those observed during the seawater uptake experiment. Indeed, the proportion of contaminant in the body wall and podia remained relatively constant throughout the experiment. Body wall and podia contained the major part (ca. $60 \%$ ) of the total body burden of ${ }^{14} \mathrm{C}-\mathrm{PCB}$, while the lowest percentage was found in the rectal caeca $(\leq 0.3 \%)$ (Table 4$)$.

\section{DISCUSSION}

The present study reports the first experimental data on the bioaccumulation kinetics of a key PCB congener in the sea star Asterias rubens, a common species widely distributed in the North Sea and NE Atlantic. The fact that organisms were also exposed to very low background concentrations of stable PCB\#153 (Table 1) showed that they were actually exposed to a global concentration of PCB\#153 that did not differ significantly from the ${ }^{14} \mathrm{C}-\mathrm{PCB}$ concentrations added experimentally to seawater or sediments (Table 1). The experimental concentrations in the seawater were

Table 3. Asterias rubens. Concentration factors, CF (maximum, minimum and mean) in body compartments after $34 \mathrm{~d}$ exposure via seawater. CFs calculated as ratio between PCB\#153 concentration in body compartments (ng g ${ }^{-1}$ total lipids) and its concentration in seawater $\left(\mathrm{ng} \mathrm{g}^{-1}\right)$. C.ds: central digestive system

\begin{tabular}{|lcccccc|}
\hline CF & Body wall & C.ds & Gonads & $\begin{array}{c}\text { Rectal } \\
\text { caeca }\end{array}$ & $\begin{array}{l}\text { Pyloric } \\
\text { caeca }\end{array}$ & Podia \\
\hline Max. & $3.91 \times 10^{5}$ & $9.16 \times 10^{4}$ & $6.01 \times 10^{4}$ & $7.90 \times 10^{3}$ & $4.75 \times 10^{4}$ & $2.43 \times 10^{5}$ \\
Min. & $3.52 \times 10^{5}$ & $5.44 \times 10^{4}$ & $2.96 \times 10^{4}$ & $4.58 \times 10^{3}$ & $1.05 \times 10^{4}$ & $1.72 \times 10^{5}$ \\
Mean & $3.74 \times 10^{5}$ & $7.50 \times 10^{4}$ & $4.62 \times 10^{4}$ & $6.76 \times 10^{3}$ & $2.31 \times 10^{4}$ & $2.17 \times 10^{5}$ \\
\hline
\end{tabular}

higher than those usually reported for PCB\#153 in natural North Sea waters. However, the latter concentrations most generally concern the dissolved fraction, whereas our measurements involved both dissolved and particulate fractions. Although available PCB data on bulk seawater samples mostly concern the sum of congeners or PCB mixture equivalents, it is noteworthy that the experimental concentrations used here were quite close (even much lower if considering extreme hot spots) to values reported for moderate to highly contaminated marine locations (Table 1). In addition, the ratio between seawater and sediment PCB concentrations added was similar to the ratio between the background PCB concentrations measured in seawater and sediments used in the experiments (Table 1). Therefore, the experimental exposures can be considered acceptable simulations of field-exposure situations that may actually occur in the field.

Data on PCB concentrations in Asterias rubens in the field are scarce, and even fewer are available for congener-specific data (e.g. Everaarts et al. 1998, den Besten et al. 2001). It is noteworthy that the total PCB\#153 concentrations (background + incorporated) reached in the pyloric caeca at the end of our experiments matched the concentrations reported in the same organs of sea stars from moderate to highly contaminated North Sea locations (Table 6). No field data were found concerning PCB concentrations in the body wall. In regard to the whole body, PCB concentrations reached in experimentally exposed sea stars were 2 to 10 times higher than the few data available from the literature (Everaarts \& 
Table 4. Asterias rubens. PCB distribution (mean $\% \pm \mathrm{SD}$, $\mathrm{n}=3$ ) in the different body compartments of the sea star after $34 \mathrm{~d}$ of exposure via seawater or sediments

\begin{tabular}{|c|c|c|}
\hline \multirow[t]{2}{*}{ Body compartment } & \multicolumn{2}{|c|}{${ }^{14} \mathrm{C}-\mathrm{PCB}-153$ distribution (\%) } \\
\hline & Seawater & Sediment \\
\hline Body wall & $68.8 \pm 1.4$ & $20.7 \pm 4.4$ \\
\hline Central digestive system & $13.9 \pm 4.1$ & $8.9 \pm 2.3$ \\
\hline Gonads & $8.4 \pm 2.5$ & $12.7 \pm 2.5$ \\
\hline Rectal caeca & $0.2 \pm 0.1$ & $0.3 \pm 0.1$ \\
\hline Pyloric caeca & $1.8 \pm 0.7$ & $5.7 \pm 1.4$ \\
\hline Podia & $6.8 \pm 1.9$ & $39.9 \pm 14.6$ \\
\hline
\end{tabular}

Fischer 1989; Table 6). However, these comparisons should be made with caution, since the field values reported by Everaarts \& Fischer we derived from sea stars collected during the spawning period. Indeed, it has been shown that the whole-body content of extractable lipids is strongly dependent on the sexual state of individuals, and may fluctuate by a factor of 2 to 3, particularly during the spawning period. This may result in a similar range of variations in PCB concentrations within a few weeks (Knickmeyer et al. 1992, Everaarts et al. 1998; Table 6).

Whether seawater or sediments were considered as a contamination source, a steady state was reached or tended to be reached in most body compartments during the course of the experiments. This suggests either that target sites are rapidly saturated, or that a metabolization mechanism is induced strongly rapidly following PCB exposure. Although a Mixed-Function Oxidases-like system has been described in pyloric caeca of Asterias rubens by den Besten et al. (1990, 1993, and den Besten 1998), it is well documented that PCB\#153 is quite resistant to biological degradation (Sipes \& Schnellmann 1987, Letcher et al. 2000) due to its specific structure, i.e. lack of hydrogen atoms on the biphenyl molecule (Borlakoglu \& Wilkins 1993). Therefore, the hypothesis regarding target-site saturation is considered to be the most plausible explanation.

It is also noteworthy that when a steady state in uptake was observed, equilibrium concentrations of PCB\#153 were generally reached quite rapidly (around Day 20), indicating that the sea star could be

Table 5. Asterias rubens. Transfer factors, TF (maximum, minimum and mean) in body compartments after $34 \mathrm{~d}$ exposure via sediments. TFs calculated as ratio between PCB\#153 concentration in body compartments (ng ${ }^{-1}$ total lipids) and its concentration in sediments (ng $\mathrm{g}^{-1}$ dry wt). C.ds: central digestive system

\begin{tabular}{|lcrcccc|}
\hline TF & Body wall & C.ds & Gonads & Rectal caeca & Pyloric caeca & Podia \\
\hline Max. & 417 & 109 & 150 & 3.43 & 70 & 863 \\
Min. & 286 & 81 & 111 & 2.91 & 55 & 258 \\
Mean & 343 & 94 & 137 & 3.10 & 61 & 479 \\
\hline
\end{tabular}

used as a bioindicator to pinpoint a PCB contamination event soon after its occurrence.

Concentrations of incorporated ${ }^{14} \mathrm{C}-\mathrm{PCB} \# 153$ at steady state were much higher (up to 300 times) in the body wall and podia than in any other compartment. Being easily dissected and constituting 70 to $80 \%$ of the total body weight, the body wall is of particular interest with respect to field surveys, and should be recommended as a body compartment to monitor complementarily to pyloric caeca - the only body compartment used in previous studies (e.g. den Besten et al. 1993, 2001, Everaarts et al. 1998).

Concentrations incorporated into the rectal caeca were always low, between 1 and 2 orders of magnitude lower than in all the other compartments. This is somewhat surprising, but could be related to the functions of the rectal caeca, which are well known to play an essential role in sea star digestion and excretion processes (Jangoux 1982, Warnau \& Jangoux 1999).

Our results have shown that PCB uptake is far more efficient in sea stars exposed to spiked seawater than in those exposed to labelled sediments when related to exposure concentrations. For a given body compartment, calculated concentration factors (CFs) based on seawater were between 2 and 3 orders of magnitude higher than transfer factors (TFs) from sediments (Tables 3 \& 5). Therefore, over the long term, despite the fact that sediments constitute the main reservoir of PCBs in the marine environment and that seawater PCB concentrations are comparatively extremely low, seawater would be an important route for PCB bioaccumulation in this sea star, as has been suggested for certain benthic infauna (e.g. Fowler et al. 1978). However, this does not imply that seawater would be the predominant pathway for PCB uptake, since our results show that final concentrations reached in the different body compartiments following the 2 types of exposure were generally of the same order of magnitude. In addition, direct trophic transfer was not addressed here, and this could also contribute significantly to PCB bioaccumulation in the sea star.

While this work constitutes the first report on PCB bioaccumulation kinetics in a sea star, several previous studies have used radiolabelled ${ }^{14} \mathrm{C}-\mathrm{PCB}$ to examine bioaccumulation kinetics in other aquatic organisms (e.g. Goerke \& Ernst 1977, Gooch \& Hamdy 1982, Schweitzer et al. 1997). However, surprisingly, these studies mostly use PCBs as Aroclor equivalents (see e.g. Butcher et al. 1997). The main advantage of the ${ }^{14} \mathrm{C}$ approach to measure PCB fluxes and transfers in aquatic biota is obviously its high sensitivity and rapidity of detection, compared to 
Table 6. Asterias rubens. Comparisons among PCB \#153 concentrations obtained in the present study (background + incorporated concentrations) and those reported for previous field studies in the North Sea. sum $_{35}$ : sum of concentration of 35 PCP congeners

\begin{tabular}{|lcll|}
\hline Body compartment & $\begin{array}{c}\text { PCB\#153 concentration } \\
\text { (ng g }{ }^{-1} \text { lipids) }\end{array}$ & Specifications & Source \\
\hline Whole body & $8190-9300$ & Experimental conditions; seawater uptake & Present study \\
& $2330-2810$ & Experimental conditions; sediment uptake & Present study \\
& $550-940$ & Spawning period 1986; Dutch coastal zone & Everaarts \& Fischer (1989) \\
& $100-235$ & Spawning period 1986; southern North Sea & Everaarts \& Fischer (1989) \\
& $4300\left(\right.$ sum $_{35}$ PCB) & Spawning period 1989; German Bight & Knickmeyer et al. (1992) \\
& $2400\left(\right.$ sum $_{35}$ PCB) & Post-spawning period 1989; German Bight & Knickmeyer et al. (1992) \\
Body wall & $728-4360$ & Experimental conditions; seawater uptake & Present study \\
& $1215-14068$ & Experimental conditions; sediment uptake & Present study \\
Pyloric caeca & $608-1111$ & Experimental conditions; seawater uptake & Present study \\
& $920-1377$ & Experimental conditions; sediment uptake & Present study \\
& $41-1054$ & Pre-spawning period 1995; southern North Sea & den Besten et al. (2001) \\
& $450-1050$ & Pre-spawning period 1995; Dutch coastal zone & Everaarts et al. (1998) \\
& $40-125$ & Pre-spawning period 1995; southern North Sea & Everaarts et al. (1998) \\
\end{tabular}

analytical techniques using gas chromatography. It therefore constitutes an interesting tool, since current research on the behaviour of PCBs in the environment tends to focus on congener-specific information (Safe 1990, Metcalfe 1994, Letcher et al. 2000). Furthermore, it allows working with low (realistic) PCB concentrations and assessment of uptake in organs which are often too small to be analyzed by classical chemical methodologies.

Acknowledgements. The IAEA Marine Environment Laboratory operates under a bipartite agreement between the International Atomic Energy Agency and the Government of the Principality of Monaco. B.D. is holder of a FRIA doctoral grant; M.W. is an Honorary Research Associate of the National Fund for Scientific Research (NFSR, Belgium). Research was partially supported by a Belgian Federal Research Programme (SSTC, Contract MN/11/30) and an NFSR fellowship to M.W.

\section{LITERATURE CITED}

Atuma SS, Linder CE, Andersson Ö, Bergh A, Hansson L, Wicklund-Glynn A (1996) CB153 as indicator for congener specific determination of PCBs in diverse fish species from Swedish waters. Chemosphere 33:1459-1464

Barnes H, Blackstock J (1973) Estimation of lipids in marine animals and tissues: detailed investigation of the sulfophosphovanillin for 'total lipids'. J Exp Mar Biol Ecol 12: 103-118

Bergen BJ, Nelson WG, Pruell RJ (1996) Comparison of nonplanar and coplanar PCB congener partitioning in seawater and bioaccumulation in blue mussels (Mytilus edulis). Environ Toxicol Chem 15:1517-1523

Boon JP, Van Zantvoort MB, Govaert MJMA (1985) Organochlorines in benthic polychaetes (Nephtys spp.) and sediments from the southern North Sea: identification of individual PCB components. Neth J Sea Res 19:93-105

Borlakoglu JT, Wilking JPG (1993) Correlations between the molecular structures of polyhalogenated biphenyls and their metabolism by hepatic microsomal monooxygenases. Comp Biochem Physiol C 105:113-117

Butcher JB, Gauthier TD, Garvey EA (1997) Use of historical PCB aroclor measurements: Hudson River fish data. Environ Toxicol Chem 16:1618-1623

Carr RS, Long ER, Windom HL, Chapman DC, Thursby G (1996) Sediment quality assessment studies of Tampa Bay, Florida. Environ Toxicol Chem 15:1218-1231

Chapman PM (1995) Ecotoxicology and pollution: key issues. Mar Pollut Bull 31:167-177

den Besten PJ (1998) Cytochrome P450 monooxygenase system in echinoderms. Comp Biochem Physiol 121(C): 139-146

den Besten PJ, Herwig HJ, Zandee DI, Voogt PA (1989) Effect of cadmium and PCBs on reproduction of the sea star Asterias rubens: aberration in the early development. Ecotoxicol Environ Saf 18:173-180

den Besten PJ, Herwig HJ, Van Donselaar EG, Livingstone DR (1990) Cytochrome P450 monooxygenase system and benzo(a)pyrene metabolism in echinoderms. Mar Biol 107: 171-177

den Besten PJ, Lemaire P, Livingstone DR, Woodin B, Stegeman JJ, Herwig HJ, Seinen W (1993) Time-course and dose-response of the apparent induction of the cytochrome P450 monooxygenase system of pyloric caeca microsomes of the female sea star Asterias rubens L. by benzo(a)pyrene and polychlorinated biphenyls. Aquat Toxicol 26:23-40

den Besten PJ, Valk S, van Weerlee E, Nolting RF, Postma JF, Everaarts JM (2001) Bioaccumulation and biomarkers in the sea star Asterias rubens (Echinodermata: Asteroidea): a North Sea field study. Mar Environ Res 51:365-387

Elder D (1976) PCBs in NW Mediterranean coastal waters. Mar Pollut Bull 7:63-64

Everaarts JM, Fischer CV (1989) Microcontaminants in surface sediments and macrobenthic invertebrates of the North Sea. NIOZ Report 1989-6. Netherlands Institute for Sea Research, Den Burg, Texel

Everaarts JM, den Besten PJ, Hillebrand MTJ, Halbrook RS, Shugart LR (1998) DNA strand breaks, cytochrome P450dependent monooxygenase system activity and levels of chlorinated biphenyl congeners in the pyloric caeca of the seastar (Asterias rubens) from the North Sea. Ecotoxicology $7: 69-79$ 
Fowler SW, Polikarpov GG, Elder DL, Parsi P, Villeneuve JP (1978) Polychlorinated biphenyls: accumulation from contaminated sediments and water by the polychaete Nereis diversicolor. Mar Biol 48:303-309

Goerke H, Ernst W (1977) Fate of ${ }^{14} \mathrm{C}$-labelled di-, tri-, and pentachlorobiphenyl in the marine annelid Nereis virens. Chemosphere 9:551-558

Gooch JA, Hamdy MK (1982) Depuration and biological halflife of ${ }^{14} \mathrm{C}$-PCB in aquatic organisms. Bull Environ Contam Toxicol 28:305-312

Harvey GR, Steinhauer WG (1976) Biogeochemistry of PCB and DDT in the North Atlantic. In: Nriagu JO (ed) Environmental biogeochemistry, Vol 1. Ann Arbor Science, Ann Arbor, p 203-221

Jangoux M (1982) Digestive systems: Asteroidea. In: Jangoux M, Lawrence JM (eds) Echinoderm nutrition. Balkema, Rotterdam, p 235-272

Knickmeyer R, Landgraff O, Steinhart H (1992) Cyclic organochlorines in the seastar Asterias rubens from the German Bight, December 1988-May 1989. Mar Environ Res 33:127-143

Laane RWPM, Sonneveldt HLA, Vander Weyden AJ, Loch JPG, Groenveld G (1999) Trend in the spatial and temporal distribution of metals $(\mathrm{Cd}, \mathrm{Cu}, \mathrm{Zn}$ and $\mathrm{Pb})$ and organic compounds (PCBs and PAHs) in the Dutch coastal zone sediments from 1981 to 1996: a model case study for Cd and PCBs. J Sea Res 41:1-17

Letcher RJ, Klasson-Wehler E, Bergman A (2000) Methyl sulfone and hydroxylated metabolites of polychlorinated biphenyls. In: Paasivirta J (ed) The handbook of environmental chemistry, Vol 3. Part K. New types of persistent halogenated compounds. Springer-Verlag, Berlin, p 315-359

Lewis JR (1978) The implications of community structure of benthic monitoring studies. Mar Pollut Bull 9:64-67

Marchand M, Abarnou A, Marcaillou-Lebaut C (1990) Les polychlorobyphényles (PCB) en milieu marin: biogéochimie et écotoxicologie. Rapp Sci Tech IFREMER (Inst Fr Rech Exploit Mer) No. 18, 162 p

Metcalfe CD (1994) Polychlorinated biphenyls. In: Kiceniuk JW, Ray S (eds) Analysis of contaminants in edible aquatic resources. VCH Verlagsgemeinschaft, Weinheim, p 305-338

Murdoch MH, Chapman PM, Norman DM, Quintino VM (1997) Spiking sediment with organochlorines for toxicity testing. Environ Toxicol Chem 16:1504-1509

Safe S (1990) Polychlorinated biphenyls (PCBs), dibenzo-pdioxins (PCDDs), dibenzofurans (PCDFs) and related compounds: environmental and mechanistic considerations

Editorial responsibility: Otto Kinne (Editor),

Oldendorf/Luhe, Germany which support the development of toxic equivalency factors (TEFs). Crit Rev Toxicol 3:293-303

Schultz-Bull DE, Petrick G, Kannan N, Duinker JC (1995) Distribution of individual chlorobiphenyls (PCB) in solution and suspension in the Baltic Sea. Mar Chem 48: $245-270$

Schweitzer LE, Hose JE, Suffet IH, Bay SM (1997) Differential toxicity of three polychlorinated biphenyl congeners in developing sea urchin embryos. Environ Toxicol Chem 16: $1510-1514$

Schweitzer LE, Bay SM, Suffet IH (2000) Dietary assimilation of a polychlorinated biphenyl in adult sea urchins ( $L y$ techinus pictus) and maternal transfer to their offspring. Environ Toxicol Chem 19:1919-1924

Sipes IG, Schnellmann RG (1987) Biotransformation of PCBs: metabolic pathways and mechanisms. In: Safe S (ed) Polychlorinated biphenyls: mammalian and environmental toxicology. Springer Verlag, Berlin, p 97-110

Stebbing ARD, Dethlefsen V, Carr M (1992) Biological effects of contaminants in the North Sea. Mar Ecol Prog Ser 91

Telli-Karakoç F, Tolun L, Henkelmann B, Klimm C, Okay O, Schramm KW (2002) Polycyclic hydrocarbons (PAHs) and polychlorinated biphenyls (PCBs) distributions in the Bay of Marmara Sea: Izmit Bay. Environ Pollut 119:383-397

Temara A, Skei JM, Gillan D, Warnau M, Jangoux M, Dubois P (1998) Validation of the asteroid Asterias rubens (Echinodermata) as a bioindicator of spatial and temporal trends of $\mathrm{Pb}, \mathrm{Cd}$, and $\mathrm{Zn}$ contamination in the field. Mar Environ Res 45:341-356

Warnau M, Jangoux M (1999) In vitro and in vivo investigations of the excretory function of the rectal caeca in the asteroid Asterias rubens (Echinodermata). Comp Biochem Physiol A 123:263-267

Warnau M, Fowler SW, Teyssié JL (1999) Biokinetics of radiocobalt in the asteroid Asterias rubens (Echinodermata): seawater and food exposures. Mar Pollut Bull 39:159-164

Weisberg S, Francisco C, Hallock D (1996) Bioaccumulation and toxicity of PCB in sea urchins exposed to contaminated sediments. Southern California Coastal Water Research Project (SCCWRP) Annual Report 1996. (SCCWRP) Westminster, CA

Wilkinson L (1988) SYSTAT: the system for statistics. SYSTAT, Evanston, IL

Wood L, O'Keefe P, Bush B (1997) Similarity analysis of PAH and $\mathrm{PCB}$ bioaccumulation patterns in sediment-exposed Chironomus tentans larvae. Environ Toxicol Chem 16: 283-292

Zar JH (1996) Biostatistical analysis, 3rd edn. Prentice-Hall, Upper Saddle River, NJ

Submitted: June 6, 2002; Accepted: February 20, 2003

Proofs received from author(s): April 28, 2003 